\title{
Aktivitas Ekonomi dan Sosial Masyarakat Di Pelabuhan Fery Jelapat I - Kuin Sebagai Sumber Belajar IPS
}

\author{
Nurlita Juliana \\ Program Studi Pendidikan IPS, FKIP Universitas Lambung Mangkurat \\ Email: nurlitajuliana26@gmail.com
}

\begin{abstract}
Abstrak
Pelabuhan fery Jelapat I - Kuin merupakan satu diantara pelabuhan kapal yang ada di Desa Jelapat I RT 21, Kecamatan Tamban dan Pelabuhan fery di Jl. Alalak Selatan Kelurahan Kuin Utara, Kecamatan Banjarmasin Utara tepatnya di Bantaran Sungai Barito. Pelabuhan ini menjadi aktivitas perekonomian dan sosial bagi masyarakat disekitarnya, sehingga aktivitas tersebut menarik untuk diteliti lebih lanjut. Karena hal tersebut dapat dijadikan sumber belajar IPS. Adapun penelitan ini bertujuan untuk 1) Mengidentifikasi aktivitas ekonomi dan sosial masyarakat di pelabuhan fery Jelapat I - Kuin 2). Mengidentifikasi kaitannya aktivitas ekonomi dan sosial masyarakat di pelabuhan fery Jelapat I - Kuin sebagai sumber belajar IPS. Penelitian inimenggunakan penelitian kualitatif. Mengenai pengumpulan data ini melalui wawancara, observasi dan dokumentasi. Hasil penelitian ini khususnya pada aktivitas ekonomi dan sosial masyarakat yaitu menunjukan bahwasanya aktivitas tersebut dapat dijadikan sumber belajar IPS karena berdasarkan hasil penelitian berbagai macam aktivitas perekenomian seperti berdagang, jasa penyeberangan sungai, membuka lowongan pekerjaan dan aktivitas badut dapat dikaitkan ke dalam sumber belajar IPS dan didalam kegiatan perekonomian itu juga terdapat aktivitas sosialnya. Pemanfaatan lingkungan sekitar sebagai sumber belajar IPS khsususnya Pelabuhan fery ini sangat bermakna dan berpotensi bagi peserta didik maupun pendidik.
\end{abstract}

\section{Kata Kunci: Pelabuhan, Ekonomi, Sosial, IPS dan Sumber Belajar IPS}

\section{PENDAHULUAN}

Kota Banjarmasin merupakan kota yang terkenal akan sungainya, yang mana kota ini sering dijuluki Kota Seribu Sungai. Ratusan sungai banyak mengalir di kota tersebut baik itu sungai-sungai besar maupun sungai kecil. Satu diantara sungai yang ada di Kota Banjarmasin yaitu Sungai Barito. Sungai Barito merupakan induk sungai terbesar yang ada Kalimantan, sungai ini menjadi penghubung Kalimantan Selatan dengan Kalimantan Tengah. Sungai Barito ini kurang lebih memiliki panjang 909 km dan lebar rata-rata sekitar 600-800 m. Selain Sungai Barito juga terdapat Sungai Martapura dan anak sungai lainnya seperti Sungai Kuin, Sungai Tamban, Sungai Anjir dan lain-lainnya. Banyak sekali anak sungai yang tidak terhitung, maka dari itu Kota Banjarmasin ini terkenal dengan Kota Seribu Sungai. (Subiyakto, B., Abbas, E W., Arisanty, D., Mutiani, M., \& akmal, H. :2020).

Semua sungai yang ada di Kota Banjarmasin ini merupakan anak sungai dari Sungai Barito, Keberadaan Sungai Barito menjadi bagian penting bagi kehidupan masyarakat baik dari segi ekonomi, budaya, agama, dan aktivitas sosialnya. Khususnya 
pada aktivitas ekonomi dan sosial di pelabuhan fery Jelapat I - Kuin, sebagian masyarakat memanfaatkan pelabuhan menjadi ladang perekonomian guna memenuhi kebutuhan hidup.

Pelabuhan fery Jelapat I-Kuin merupakan pelabuhan yang yang berlokasi di Jelapat I Kecamatan Tamban dan Alalak Selatan Kecamatan Banjarmasin Utara, yang mana pelabuhan tersebut terdapat beberapa buah fery yang menjadi jasa transportasi Sungai Barito untuk menyeberangi sungai baik yang menuju Jelapat I - Kuin ataupun sebaliknya. Disekitar pelabuhan juga terdapat permukiman warga sehingga warga memiliki kesempatan untuk membuka usaha warung atau kedai disekitar pelabuhan fery tersebut. Mengenai aktivitas perekonomian dan sosial masyarakat disana dapat digunakan sebagai bahan matei di sekolah khususnya dijenjang SMP pada mata pelajaran Ilmu Pengetahuan Sosial (IPS).

Dalam jurnal (Supardi, A. W. :2014), IPS merupakan mata pelajaran pada jenjang pendidikan di tingkat sekolah, yang dikembangkan secara terintegrasi dengan mengambil konsep-konsep esensial dari Ilmu-ilmu Sosial dan humaniora. IPS mengkaji berbagai fenomena kehidupan dan masalah sosial yang diorganisasikan dan disajikan secara ilmiah pedagogis dan psikologis, yang telah disederhanakan, diseleksi, dan diadaptasi untuk kepentingan pencapaian tujuan pendidikan.

Melalui pembelajaran IPS upaya pengembangan iklim yang kondusif bagi peserta didik untuk belajar sekaligus melatih pengetahuan, nilai, dan keterampilannya selama pembelajaran. Mengenai aktivitas belajar peserta didik, Pembelajaran IPS harus mampu menghasilkan berbagai pengalaman belajar. Melibatkan peserta didik pada aktivitas belajar tujuannya untuk menjadikan peserta didik memiliki kemampuan memecahkan masalah dalam lingkungan belajar sebagaimana keabsahan yang sesungguhnya.

Permasalahan umum dalam dunia pendidikan di Indonesia yaitu sistem pembelajaran yang kurang baik, misalnya metode pembelajaran yang digunakan di sekolah dirasa kurang tepat atau kurang menarik minat peserta didik. Padahal Banyak berbagai strategi pembelajaran yang dapat diterapkan dalam pembelajaran IPS. Satu diantaranya yaitu memanfaatkan lingkungan lokal sebagai Sumber Belajar IPS. Sumber belajar adalah segala suastu yang dapat digunakan oleh peserta didik unutk mempelajari suatu hal apapun dan sumber belajar ini ini tidak terbatas hanya pada buku saja namun dapat berupa alat, bahan, lingkungan, ataupun orang intinya yang dapat mendukung untuk proses pembelajaran (Syaharuddin, S., \& Mutiani :2020). Sumber 
Belajar IPS yang digunakan adalah lingkungan, yaitu para peserta didik belajar, seperti ruang kelas, perpustakaan sekolah ataupun daerah, laboratorium IPS,masyarakat dan alam sekitar dari peserta didik ( Abbas, E. W, Hidayat Putra, M.A \& M, R. :2019) Untuk itu sebagai pendidik harus mampu memanfaatkan lingkungan lokal sebagai Sumber Belajar karena tujuan diajarkannya IPS ini untuk mengembangkan potensi peserta didik mengenai pengetahuan, sikap, keterampilan dan nilai-nilai disekitar masyarakat sehingga memanfaatkan lingkungan sebagai sumber belajar IPS akan mempermudah peserta didik untuk menggali potensinya. (Subiyakto, B., \& Mutiani, M. :2019)

\section{METODE PENELITIAN}

\section{Jenis Penelitian}

Jenis penelitian yang digunakan yaitu penelitian Kualitatif yang mana peneliti ini bertujuan untuk mendeskripsikan kehidupan ekonomi dan sosial masyarakat disekitar pelabuhan fery Jelapat I - Kuin. Menurut (Saryono :2010) dalam bukunya Penelitian Kualitiaf merupakan penelitian yang dipakai untuk menggambarkan, menyelidiki dan menjelaskan keunikan dari pengaruh sosial yang tidak mampu dijelaskan, digambar, maupun diukur menggunakan penelitian kuantitatif. Penelitian kualitatif ini berusaha untuk menghasilan data uraian baik berupa kata-kata maupun percakapan dari beberapa orang dan perilaku yang diteliti.

\section{Tempat dan Waktu Penelitian}

Tempat Penelitian ini adalah di wilayah pesisir Pelabuhan fery Desa Jelapat I RT 21, Kecamatan Tamban dan Pelabuhan fery di J1. Alalak Selatan Kelurahan Kuin Utara, Kecamatan Banjarmasin Utara. Waktu Penelitian ini dilaksakan pada Kamis, 18 Februari 2021 - Kamis, 11 Maret 2021.

\section{Sumber Data}

Data yang diinginkan pada penelitian ini mengenai aktivitas ekonomi dan sosial masyarakat di sekitar pelabuhan fery Jelapat I - Kuin. Penelitian ini menggunakan dua data yakni data primer dan data sekunder. Data primer merupakan data yang didapatkan langsung dari pihak terkait yang didapatkan dari hasil wawancara. Data sekunder merupakan data yang diperoleh dari buku-buku, jurnal dan sumber lainnya yang digunakan untuk melengkapi hasil penelitian di lapangan (Putro, Herry Porda Nugroho, and Jumriani, J. :2020) 


\section{Teknik Pengumpulan Data}

Penelitian ini menggunakan metode observasi, wawancara dan dokumentasi. Observasi ini teknik pengumpulan data yang dilakukan secara langsung mengamati ke tempat lokasi penelitian. Wawancara teknik pengumpulan data yang dilakukan menggunakan beberapa pertanyaan untuk dijawab kepada pihak terkait guna mencari informasi lebih mendalam. Dokumentasi teknik pengumpulan data yang dilakukan berupa foto.

\section{HASIL DAN PEMBAHASAN}

Pelabuhan fery Jelapat I- Kuin terletak di Pelabuhan fery Desa Jelapat I RT 21, Kecamatan Tamban dan Pelabuhan fery di Jl. Alalak Selatan Kelurahan Kuin Utara, Kecamatan Banjarmasin Utara. Pelabuhan ini berada di Bantaran Sungai Barito yang menjadi pusat perekonomian sejak tahun 1998 hingga sekarang. Pelabuhan ini menjadi penghubung Kecamatan Tamban - Kota Banjarmasin. Adanya penyeberangan ini bertujuan untuk mempermudah masyarakat Jelapat I dan sekitarnya bepergian ke Kota Banjarmasin maupun sebaliknya yang menggunakan kendaraan. Sebelum adanya akses menggunakan feri, masyarakat melalui jalur darat yang mana jalan tersebut melalui Jalan Trans Kalimantan Anjir Muara dengan jarak tempuh kurang lebih 70 menit dari Jelapat 1 menuju kota Banjarmasin.

\section{Aktivitas Ekonomi Masyarakat Pelabuhan Fery Di Jeapat I - Kuin}

Pelabuhan merupakan satu diantara sarana prasarana yang cukup penting bagi masyarakat khususnya pada pelabuhan fery Jelapat I - Kuin dan sebaliknya. Pelabuhan dapat menjadi peran dalam menggairahkan kegiatan ekonomi masyarakat. Dengan adanya pelabuhan ini juga menguntungkan pada hal pengembangan wilayah yang mana pengembangan wilayah menjadi cara penambahan nilai tambah yang dimiki disuatu daerah untuk meningkatkan kualitas hidup maupun meningkatkan kekayaan suatu daerah. Pengembangan ini juga merupakan menjadikan masyarakat untuk memanfaatkan sungai ataupun lingkungan sekitar sebagai pemenuhan kebutuhan hidup.

Dengan adanya pelabuhan ini, maka keutungan dari aspek ekonomi memberi kesempatan kepada masyarakat sekitar karena ada lapangan pekerjaaan seperti jasa pengelola fery, membuka warung/kedai dan atraksi badut jalanan Perkembangan aktivitas ekonomi sebelum adanya pelabuhan sampai sesudah ada pelabuhan ini terdapat peningkatan pendapatan, khususnya pada masyarakat yang mengelola fery, pemilik usaha warung/kedai dan atraksi badut jalanan disekitar pelabuhan. 
Adanya pelabuhan fery ini menjadi peluang masyarakat untuk memberikan jasa transpotasi air kepada masyarakat yang ingin menyeberangi sungai. Sehingga pula adanya Kapal fery ini memberikan kesempatan kepada masyarakat sekitar untuk mengelolanya. Feri yang digunakan untuk penyeberangan yakni kapal besar. Kapal feri yang terdaftar terdapat 6 unit, akan tetapi yang beroprasi dalam sehari terdapat 3 unit. Berdasarkan hasil wawancara menurut Bapak Abu Bakar satu diantara Pemilik Kapal Fery, Pada kapal feri ini mampu menampung kendaraan roda 2 hingga 50-60 unit motor dan feri ini dikhususkan untuk menampung pengendara bermotor dan bersepeda. Tarif harga yang ditetapkan Provinsi 7000/motor dan 3000/sepeda. Namun ada tarif harga tersendiri khususnya yang berstatus pelajar maupun mahasiswa yakni 5000/motor dan berjalan hanya 2000/orang. Fasilitas yang ada didalam kapal besar tersebut satu diantaranya yaitu tempat duduk yang memanjang untuk penumpang, beberapa baju pelampung kecil maupun besar, sebagian kapal ada warung kecil-kecilan didalamnya dan Jamban (Toilet). Pada kapal feri tersebut terdapat beberapa orang petugas untuk mengelolanya, yang mana ada yang bertugas menjadi Nahkoda, menjaga karcis pembayaran Fery dan bertugas menyusun kendaraan penumpang. Jumlah yang bertugas terdapat 4-5 Orang. Keuntungan yang dicapai mengelola kapal ini sekitar Rp. 2.000.000 -3.000 .000 perbulan.

Banyak masyarakat yang membuka warung/kedai kecil-kecilan di sekitar area pelabuhan bahkan di dalam Kapal fery juga terdapat warung. Dari hasil wawancara dan penelitian, adanya pelabuhan fery ini meningkatkan penghasilan masyarakat yang membuka warung/kedai. Masyarakat yang berjualan di dalam kapal fery menjual minuman air maupun makanan seperti mie bancir/mie merah, Lapat khas Banjarmasin, gorengan dan makanan ringan lainnya. Masyarakat yang disekitar pelabuhan ada yang berjualan minuman es, pentol dan juga rujak. Jumlah pedagang yang mendirikan beberapa kion atau warung makan yang berjualan dirumah dekat pelabuhan fery Jelapat I - Kuin sekitar $5-7$ warung.

Selain itu juga banyak orang dewasa dan anak-anak mencari nafkah menjadi aktraksi badut jalanan di sekitar pelabuhan. Namun yang paling banyak berperan sebagai atraksi badut disekitar pelabuhan ini adalah anak-anak. Mulai dari pagi hari sampai sore menjelang magrib mereka mangkal di sekitar pelabuhan fery karena menurutnya di pelabuhan ini lokasi yang tepat mencari nafkah. 


\section{Aktivitas Sosial Masyarakat Pelabuhan Fery di Jelapat I - Kuin}

Aktivitas kehidupan sosial masyarakat disekitar pelabuhan tidak lepas adanya rasa kebersamaan antara individu dengan kelompok. Meskipun tidak mengenal satu sama lain pada pelabuhan tersebut menjadi tempat pertemuan orang baru karena khususnya dalam fery tersebut banyak penumpang yang tidak dari daerah Jelapat sekitar melainkan dari berbagai daerah. Hubungan timbal balik pun terjadi tanpa memandang status sosial. Adanya aktivitas sosial ini menjadi bukti bahwa adanya terikat interaksi pada mereka. Bentuk aktivitas sosial ini terbentuk pada karyawan jasa fery yang mana karyawan tersebut saling membantu menyusun kendaraan di dalam fery karena itu memang tugas dari seorang karyawan pengelola fery.

Di warung sekitar pelabuhan juga terdapat interaksi antara penjual dan pembeli, pemilik warung melayani pembeli, sehingga satu sama lain saling menguntungkan. Tidak hanya menjadi tempat interaksi berdagang masyarakat yang berjualan disana melainkan juga berdagang sambil melawak untuk mendapatkan suasana agar pembeli juga terhibur. Selain menjadi pusat perdagangan dan jasa penyeberangan fery, banyak masyarakat khususnya remaja di sekitar Jelapat I yang menfaatkan pelabuhan untuk tempat Jogging (Lari Santai) bahkan menjadikan tempat wisata pada pagi hari dan menjelang magrib khususnya para remaja. Karena saat pagi hari muncul Sun rice (matahari terbit) dan Sun Set (matahari terbenam) yang menghiasi langit yang begitu indah dan juga kelotok-kelotok yang beroprasi di Sungai Barito menjadi nilai tambah penghias pagi maupun senja. Kelompok remaja mengambil kesempatan itu untuk mengekspresikan diri untuk berfoto di sekitaran pelabuhan. Kehidupan sosial masyarakat ini sangat dipengaruhi oleh lingkungan.

\section{Aktivitas Ekonomi dan Sosial Masyarakat Pelabuhan Fery Jelapat I - Kuin Sebagai Sumber Belajar IPS}

Aktivitas ekonomi dan sosial masyarakat pelabuhan fery Jelapat I - Kuin merupakan satu diantara aspek yang dapat gunakan untuk kepentingan sumber belajar khususnya pembelajaran IPS. (Putro, H.P. N \& Jumriani, J :2020). Untuk mewujudkan Pembelajaran IPS yang Powerful maka harus mampu memanfaatkan lingkungan lokal masyarakat sebagai sumber belajar, sehingga peserta didik tidak hanya paham pada materinya saja namun juga mampu memahami secara kontekstual. Dalam jurnal (Widiastuti, E. H. :2017) mengatakan Sumber belajar IPS yang memanfaatkan lingkungan disekitar ini akan mempermudahkan peserta didik dalam memahami materi 
pembelajaran yang dipelajari. Mengaitkan suatu materi pelajaran IPS dengan lingkungan masyarakat akan memberikan kesempatan kepada peserta didik untuk berperan langsung atau berpartisipasi dalam masyarakat melakukan tindakan (action).

Pada aktvitas ekonomi dan sosial masyarakat di pelabuhan fery Jelapat I - Kuin ini dapat dijadikan sumber belajar IPS karena aktivitas tersebut dapat dikaitkan dalam materi pendidikan IPS SMP. Berikut ini penjelasan mengenai hal tersebut yaitu:

1. Pemanfaatan Kehidupan Ekonomi dan Sosial Pada materi Ekonomi IPS SMP Kelas VII Semester II satu diantaranya mengaitkan ke BAB III Aktivitas Manusia Memenuhi Kebutuhan pada bagian Kebutuhan Manusia, yang mana di buku IPS dijelaskan macam-macam kebutuhan menurut Subjek pada kebutuhan individu sehingga adanya niat untuk menghadirkan Kapal fery untuk membuka usaha Jasa penyeberangan merupakan kebutuhan yang dirasakan secara individual/perorangan. Pada Kebutuhan kelompok dapat dikaitkan karena adanya pelabuhan dan jasa penyeberangan sungai ini sekelompok masyarakat secara bersama-sama kebutuhannya terpenuhi. Contoh: Kebutuhan akan jasa penyeberangan fery ini berperanguh pada masyarakat yang membutuhkan dengan adanya fery ini ingin orang yang ingin berangkat bekerja, sekolah dan bepergian jauh tidak terkendala oleh jarak tempuh dan adanya pelabuhan ini masyarakat dapat membuka usaha kecil-kecilan. Jadi satu sama lain saling menguntungkan.

2. Aktivitas ini juga dapat dikaitkan kedalam Tindakan, Motif dan Prinsip ekonomi karena didalam buku IPS dijelaskan bahwa manusia melakukan berbagai kegiatan agar kebutuhan hidupnya terpenuhi segala kegiatan manusia untuk memenuhi kebutuhan hidupnya disebut dengan tindakan ekonomi. Jadi masyarakat yang memanfaatkan pelabuhan untuk membuka warung ataupun menjadi karyawan mengelola fery bahkan menjadi pemilik usaha jasa kapal fery merupakan suatu tindakan ekonomi karena disana terdapat kegiatan ekonomi untuk memenuhi kebutuhan hidup. Selanjutnya yaitu pada motif ekonomi, keinginan atau alasan yang mendorong manusia untuk melakukan tindakan disebut dengan motif ekonomi. Jadi, motif ekonomi khususnya untuk memenuhi kebutuhan dapat dikaitan dengan aktivitas di pelabuhan karena masyarakat mengharapkan mendapatkan pengahasilan dengan cara bekerja disana. Contoh: masyarakat yang membuka warung, bekerja sebagai karyawan pengelola fery dan menjadi aktraksi badut jalanan tujuannya untuk mendapatkan tambahan pengahasilan keluarga. 
3. Aktivitas ekonomi dan sosial di pelabuhan ini juga dapat dikaitkan kedalam materi BAB II Semester I yakni Interaksi Sosial yang mana masyarakat secara tidak langsung menghadirkan hubungan sosial baik antara individu, individu dengan kelompok ataupun antar kelompok. Interaksi sosial ini berlangsung pada kegiatan ekonomi masyarakat dan dapat dijadikan materi mengenai bentuk maupun sifat interaksi yang tersedia di materi pembelajaran IPS SMP. Ini dikarenakan di Pelabuhan fery Jelapat I - Kuin terlihat bahwa adanya sifat interaksi mengenai asosiatif, disasosiatif dan adanya kerjasama maupun persaingan antar pedagang disana. Dengan mengaitkan aktivitas disana peserta didik hanya mendapatkan pengetahuan namun aktivitas tersebut menimbulkan makna yang dipahami peserta didik bahwa segala kegiatan manusia tidak lepas dari adanya interaksi sosial.

4. Pemanfaatan Kehidupan Ekonomi dan Sosial Pada materi Ekonomi IPS SMP Kelas VIII Pada BAB II Pengaruh Interaksi Sosial terhadap kehidupan sosial dan kebangsaan Khususnya pada materi Mobilitas sosial yang mana materi ini menjelaskan perpindahan dari status kelas sosial ke kelas lainnya. Dalam bentuk bentuk mobilitas sosial terdapat mobilitas vertikal dan horizontal. Sehingga kegiatan ekonomi masyarakat disana dapat dikaitkan materi ini contohnya pada pemilik kapal fery, beliau sebelum memiliki usaha jasa penyeberangan beliau hanya sebagai petani, namun dengan adanya jasa fery ini belian memiliki penghasilan tetap. Sehingga dapat dikatakan perpindahan status sosial dari bawah hanya sebagai petani menjadi bos pemilik usaha jasa penyeberangan fery.

\section{SIMPULAN}

Berdasarkan hasil penelitian yang mana kehidupan ekonomi masyarakat memanfaatkan pelabuhan fery Jelapat I - Kuin untuk meemenuhi kebutuhan hidupnya dengan cara memberikan jasa tumpangan penyeberangan menggunakan kapal fery beserta karyawan yang mengelolanya, mendirikan warung/kedai disekitarnya dan para atraksi badut jalanan ikut berperan disana. Selain itu, terdapat kehidupan social masyarakat disana yang mana adanya pelabuhan tersebut masyarakat satu sama lain saling berinteraksi dan saling tolong menolong. Terkait dengan sumber belajar, pada kegiatan ekonomi dan social masyarakat di pelabuhan fery Jelapat - Kuin dapat dijadikan sumber belajar IPS seperti materi pada IPS SMP Kelas VII BAB II tentang Interaksi Sosial, BAB III Aktivita Mansuia dalam Memenuhi Kebutuhan, dan materi Kelas VIII Kelas VIII Pada BAB II Pengaruh Interaksi Sosial terhadap kehidupan sosial dan kebangsaan. 


\section{DAFTAR PUSTAKA}

ABBAS, E W., Hidayat Putra, M A., \& Noor Handy, M. R, (2019). Laporan Penelitian: PEMANFAATAN EKOWISATA SUNGAI MARTAPUR KOTA BANJARMASIN SEBAGAI SUMBER BELAJAR IPS.

Putro, H.P. N \& Jumriani, J :2020. KEHIDUPAN SOSIAL DAN EKONOMI MASYARAKAT BANTARAN SUNGAI A SEBAGAI SUMBER BELAJAR IPS.

Syaharuddin, S., \& Mutiani (2020). Strategi pembelajaran IPS: Konsep dan Aplikasi.

Subiyakto, B., Abbas, E W., Arisanty, D., Mutiani, M., \& akmal, H. (2020). Sungai dan Kehidupan Masyarakat Banjar: Penguatan Lokalitas dalam Wacana Pendidikan IPS yang Responsif.

Subiyakto, B., \& Mutiani, M. (2019). Interelasi nilai Pendidikan melalui aktivitas masyarakat sebagai sumber belajar Ilmu Pengetahuan Sosial. Khazanah: Jurnal Studi Islam dan Humaniora, 17 (1) 137-166

Supardi, A. W. (2014). PEMANFAATAN LABORATORIUM IPS SMP. JIPSINDO, 2(1). 